\title{
Identidade do Apple stem pitting virus em São Paulo, Brasil, Confirmada por Meio de RT-PCR
}

\author{
Juliana Freitas-Astua ${ }^{1}$, Quelmo S. de Novaes $^{2}$, Juarez A. Betti ${ }^{3}$, Jorge A. M. Rezende' ${ }^{2}$ Hugo Kuniyuki ${ }^{3}$ \& \\ Valdir A. Yuki ${ }^{3}$
}

'Embrapa Milho e Sorgo / Centro APTA Citros 'Sylvio Moreira', CEP 13490-970, Cordeirópolis, SP, ${ }^{2}$ Departamento de Entomologia, Fitopatologia e Zoologia Agrícola, ESALQ, USP, CEP 13418-900, Piracicaba, SP, ${ }^{3}$ Centro de Fitossanidade, Instituto Agronômico (IAC), CEP 13020-902, Campinas, SP, e-mail: jabetti@iac.sp.gov.br

(Aceito para publicação em 31/03/2004)

Autor para correspondência: Juarez Antonio Betti

\begin{abstract}
Identity of Apple stem pitting virus in São Paulo, Brazil, confirmed by RT-PCR

Biological indexing of apple (Malus domestica) clones AnnaEF 263/2 and Ohio Beauty 270/6B, collected in Angatuba and Paranapanema counties, Brazil, where shown to be infected by Apple stem pitting virus (ASPV). Thermotherapy associated with tip culture,

produced clones Anna-EF T-711 and Ohio Beauty T-597, and biological indexing showed that clones were virus free. The RT-PCR with total RNAs extracted from clones using the primers that amplified a region within the coat protein gene of ASPV, confirmed the biological assays. Partial nucleotide and deduced amino acid sequences of the coat protein gene showed high similarity with sequences of ASPV in GenBank.
\end{abstract}

O vírus do estriamento do lenho da macieira (Apple stem pitting virus - ASPV), gênero Foveavirus, descrito em Virginia crab, causa sintomas em outras indicadoras (Acta Horticult. 386:72. 1995). No Brasil, a sua detecção biológica em macieira (Malus domestica Borkh.) envolveu as indicadoras M. platycarpa Rehd. (Summa Phytopathol. 5:29. 1979), Spy 227 (Fitopatol. bras. 8:620. 1983), Pyronia veitchii (Trabut) Guill. e Virginia crab (M. pumila Mill.) (Summa Phytopathol. 21:49. 1995). A mancha anelar do marmeleiro (Cydonia oblonga Mill.) (O Biológico 25:64. 1959), semelhante à doença "Quince sooty ringspot" atribuída ao ASPV (Acta Horticul. 386:148. 1995), provavelmente constitui o primeiro relato envolvendo esse vírus no Brasil.

Para confirmar a identidade do ASPV, foram utilizados quatro clones de macieira mantidos em casa de vegetação no IAC, em Campinas, $\mathrm{SP}$ e testados com as quatro indicadoras já citadas. Os clones infetados 263/2 (Anna-EF) e 270/6B (Ohio Beauty) foram coletados respectivamente em Angatuba e Paranapanema, SP. Os clones sadios T-711 e T-597 resultaram de termoterapia e propagação de ápices (Summa Phytopathol. 10:128. 1984) dos clones 263/2 e 270/6B, respectivamente.

Na ESALQ/USP, Piracicaba, SP, RNAs totais foram extraídos de tecidos foliares seguindo protocolo de Gibbs \& Mackenzie (J. Virol. Meth. 63:9. 1997) e utilizados em análise

de RT-PCR para ASPV com os iniciadores específicos ASPC: (5'-CTCTTGAACCAGCTGATGGC-3') e ASP-A (5'-ATA GCCGCCCCGGTTAGGTT-3') (J. Phytopathol. 145:499. 1997). Fragmentos de 244-pb, correspondentes a uma região do gene que codifica a proteina da capa protéica $(\mathrm{CP})$ do vírus, foram amplificados apenas a partir de RNAs extraídos dos clones de campo (263/2 e 270/6B) e não dos de termoterapia, confirmando os resultados dos testes biológicos.

O produto da RT-PCR obtido do clone 270/6B foi clonado, sequenciado e gerou dois consensos de 158 nucleotídeos: um deles, com dois clones e o outro, com quatro. As sequiências de nucleotídeos e de aminoácidos deduzidos da CP do consenso 1 apresentaram $85 \%$ e $96 \%$ de similaridade, respectivamente, com as sequiências do ASPV disponíveis no GenBank (acesso AF345892). Para o consenso 2, os valores de similaridade foram de $84 \%$ e $98 \%$, respectivamente, quando comparados com os do acesso AF438522 do ASPV depositado no GenBank.Quando comparados entre si, os dois consensos apresentam $87 \%$ de identidade de nucleotídeos e $100 \%$ de aminoácidos deduzidos, indicando uma aparente variabilidade na sequiência de DNA, sem que haja implicações na tradução de proteína (Figura 1). Esses resultados confirmam a identidade de isolados do ASPV que ocorrem em macieira em São Paulo.

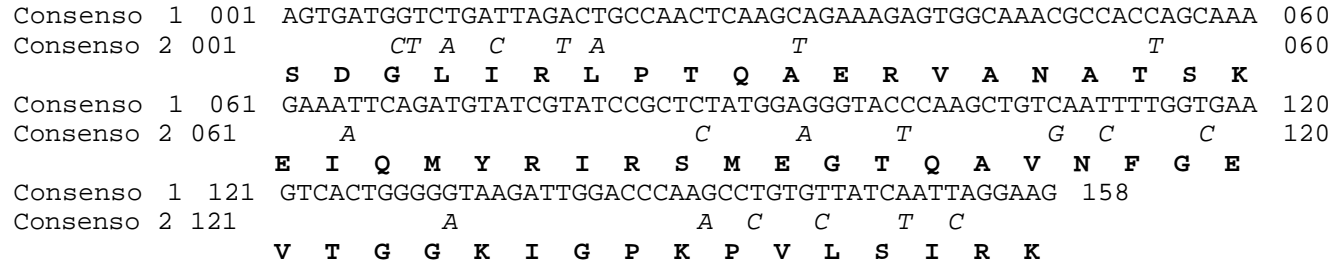

FIG. 1 - Seqüências parciais de nucleotídeos dos consensos 1 e 2 (parte superior, com as variações dos dois consensos em itálico) e aminoácidos deduzidos (inferior, em negrito) do gene da capa protéica do Apple stem pitting virus 